\title{
Factors influencing bromsulphalein retention and its evaluation in bilharzial hepatic fibrosis
}

\author{
H. S. BADAWI, A. M. NOMEIR, AND R. A. ZAHER \\ From the Department of Medicine, Faculty of Medicine, Alexandria University, Egypt
}

EDITORIAL SYNOPSIS Thirty-six patients with bilharzial hepatic fibrosis were investigated, and five other patients were studied before and after portacaval shunt operation. The liver parenchyma is well preserved in bilharzial hepatic fibrosis and this is reflected in the almost normal results of liver function tests. In $40 \%$ of the patients bromsulphalein was retained to an abnormal degree and retention was increased post-operatively in the patients studied before and after portacaval shunt operations. The increased retention of bromsulphalein was found to be the result of prehepatic factors, namely, diminished hepatic blood flow and increased systemic portal collateral circulation either singly or in combination.

In schistosomal hepatic fibrosis the various liver function tests give normal or only slightly abnormal results, particularly in tests depending on alterations in the serum proteins; these are not specific for liver diseases. Most other liver function tests yield normal results except the bromsulphalein retention test. This fact stimulated us to search for factors other than liver cell dysfunction which might modify the results.

\section{PROCEDURE}

Thirty-six patients with confirmed bilharzial hepatic fibrosis were studied. In addition to routine investigations, the icterus index, thymol turbidity, plasma proteins, and prothrombin activity were estimated.

Bromsulphalein was injected intravenously in a dose of $2 \mathrm{mg} . / \mathrm{kg}$. body weight (Kolmer, Spaulding, and Robinson, 1952), and a sample of blood from the opposite arm was collected half an hour after the injection. Blood was then left to coagulate and serum was separated by centrifuging and 2 drops of a $10 \%$ solution of sodium hydroxide were added to the serum to bring out the colour. The amount of the dye retained in the serum was estimated by direct comparison with prepared standards. Retention of more than $10 \%$ of the dye was considered abnormal.

The portal pressure was measured by the intrasplenic technique in all the patients, the hepatic vein was catheterized in 26 , the pressures were recorded in all, and the hepatic blood flow was estimated in 15 of them by the bromsulphalein clearance technique.

Liver biopsy specimens were obtained and examined in 28 patients.

Various tests were carried out to prove and assess the degree of systemic portal collateral circulation. These included radiological examination of the oesophagus for oesophageal varices. Portal collateral veins on the anterior abdominal wall were sought and demonstrated in some patients by infra-red photography. Splenoportography was carried out in 34 patients to study the intra-abdominal portal collateral veins, and haemorrhoids were detected by proctoscopy.

We also studied the results of bromsulphalein retention and other liver function tests in five patients with bilharzial hepatic fibrosis before and after portacaval shunt operations.

\section{RESULTS}

Results of bromsulphalein retention tests ranged from 2 to $36 \%$ of the injected dye. Normal values (up to $10 \%$ ) were observed in 21 patients, while abnormal results ranging from 12 to $36 \%$ were detected in the remaining 15 patients. It will be seen from Table I that of the liver function tests carried out in this study, the bromsulphalein retention test was the only one to show deviation from the normal in about two-fifths of the cases studied $(41 \cdot 6 \%)$. Two patients showed low values for prothrombin activity which was readily corrected by parenteral administration of vitamin $\mathrm{K}$, in other words, hypoprothrombinaemia was not secondary to hepatocellular dysfunction.

Liver biopsy material was obtained in 28 patients, and examination showed the usual microscopic appearances of bilharzial liver fibrosis. The liver parenchyma was intact and showed no attempt at regeneration. A few layers only of liver cells were compressed and atrophied at the periphery of the 
TABLE I

RELATION BETWEEN LIVER FUNCTION TESTS, PATHOLOGY, AND PORTAL HAEMODYNAMICS

No. Liver Function Tests
Thymol Turbidity
Biopsy

Bromsulphalein \begin{tabular}{l} 
Pressures $\left(\mathrm{cm} . \mathrm{H}_{2} \mathrm{O}\right)$ \\
\hline $\begin{array}{l}\text { Occluded Hepatic } \\
\text { Vein }\end{array}$
\end{tabular} lobule in 10 patients. The lobular pattern was normal in all. All the changes were in the portal tracts which contained granulomatous formation, cellular infiltration, and variable grades of fibrosis. No correlation could be seen between the degree of fibrosis and the results of bromsulphalein retention tests.

Portal pressure, as measured through the occluded hepatic catheter or by the intrasplenic method, showed no correlation with the results of the bromsulphalein retention test.

Systemic portal collateral veins were found to a variable degree in 25 patients, and radiological examination of the oesophagus showed definite varicose veins in 12 patients. Splenoportography failed to demonstrate collaterals in 19 patients; in the remaining 15 patients collaterals were visualized, and were marked in seven, moderate in six, and mild in two patients. Systemic portal collateral veins as a whole were graded as absent or insignificant, moderate, and marked. Fifteen patients showed none or insignificant collateral veins, nine had moderately defined collateral veins, and the remaining 12 had marked veins. Correlation of the degree of col- lateral circulations with the results of a bromsulphalein retention test showed that the retention was maximum in patients with marked portal collateral veins. Thus of the 12 patients who had marked collateral veins eight had bromsulphalein retention values of more than $10 \%$. Of the nine patients who had moderate veins, four had bromsulphalein retention values more than $10 \%$, while of the 14 patients who had no or insignificant veins only three had retention values more than $10 \%$. Table II and Fig. 1 show the relationship between these findings.

Hepatic blood flow was estimated in 15 patients. It ranged between 785 and $1,630 \mathrm{ml} . / \mathrm{min}$., and it was found that there was greater retention of bromsulphalein in the patients with a low hepatic blood flow. In 13 patients the hepatic blood flow was below $(1,490 \mathrm{ml} . / \mathrm{min}$.) the normal mean (Nomeir, 1960; Bradley, Ingelfinger, Bradley, and Curry, 1945). The normal range is 1,085 to $1,845 \mathrm{ml} . / \mathrm{min}$. (Bradley, 1949; Bradley et al., 1945). Of the 15 patients, six had a hepatic blood flow rate above $1,000 \mathrm{ml}$./min., five of them had $5 \%$ bromsulphalein retention and the sixth patient showed $10 \%$ reten- 
TABLE II

RELATION OF BROMSULPHALEIN RETENTION TEST TO THE DEGREE OF SYSTEMIC PORTAL COLLATERALS

\begin{tabular}{lccc}
\multirow{2}{*}{$\begin{array}{l}\text { Degree of } \\
\text { Collaterals }\end{array}$} & \multicolumn{3}{l}{ Percentage Retention of Bromsulphalein } \\
\cline { 2 - 4 } & Absent or Slight & Moderate & Marked \\
\hline 22 & 14 & 10 \\
$3 \cdot 2$ & 12 & 26 \\
6 & 2 & 12 \\
4 & 10 & 32 \\
8 & 36 & 20 \\
16 & 26 & 15 \\
4 & 8 & 15 \\
& 14 & 5 & 10 \\
10 & 10 & 10 \\
& 5 & & 10 \\
& 5 & & 15 \\
Average & 5 & &
\end{tabular}

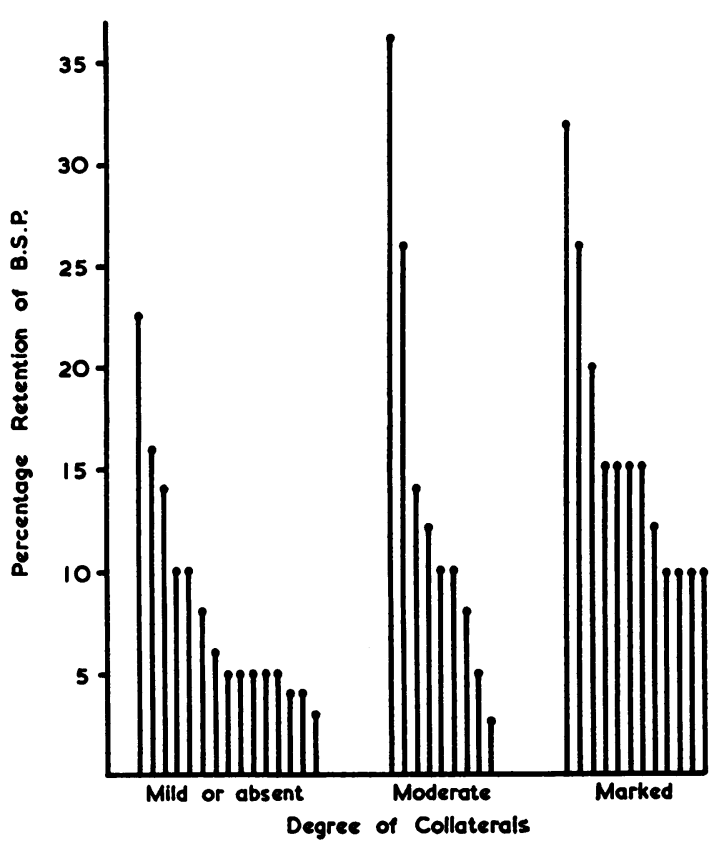

FIG. 1. Relation between systemic portal collateral circulation and retention of bromsulphalein.

tion. In the remaining nine patients the hepatic blood flow was below $1,000 \mathrm{ml} . / \mathrm{min}$. and in all except two the bromsulphalein retention was 10 to $15 \%$ (Table III); the two patients who showed low retention values $(8 \%$ and $5 \%)$ had hepatic blood flows of 947 and $925 \mathrm{ml} . / \mathrm{min}$. respectively. Of the 15 patients, all who exhibited retention of bromsulphalein of more than $10 \%$ had a hepatic blood flow rate below $1,000 \mathrm{ml} . / \mathrm{min}$.
TABLE III

RELATION BETWEEN BROMSULPHALEIN RETENTION VALUES AND ESTIMATED HEPATIC BLOOD FLOW

\begin{tabular}{rccl}
$\begin{array}{l}\text { Case } \\
\text { No. }\end{array}$ & $\begin{array}{l}\text { Estimated Hepatic } \\
\text { Blood Flow } \\
\text { (ml./min.) }\end{array}$ & $\begin{array}{l}\text { Bromsulphalein } \\
\text { Retention }(\%)\end{array}$ & $\begin{array}{l}\text { Degree of } \\
\text { Collaterals }\end{array}$ \\
\hline 1 & 1,630 & 10 & Moderate \\
2 & 1,610 & 5 & Absent \\
3 & 1,390 & 5 & Absent \\
4 & 1,285 & 5 & Mild \\
5 & 1,055 & 5 & Moderate \\
6 & 1,042 & 5 & Absent \\
7 & 947 & 8 & Moderate \\
8 & 925 & 5 & Mild \\
9 & 905 & 15 & Marked \\
10 & 900 & 10 & Marked \\
11 & 900 & 10 & Marked \\
12 & 885 & 10 & Marked \\
13 & 875 & 15 & Marked \\
14 & 860 & 15 & Marked \\
15 & 785 & 15 & Marked
\end{tabular}

Table IV shows the results of bromsulphalein retention in the five patients studied before and after portacaval shunt operations. All of them showed a marked increase in the retention of the dye after the operation without any of the manifestations of parenchymal liver insufficiency. The other liver function tests were normal before operation and remained unaffected post-operatively. The retention of bromsulphalein before operation ranged from 0 to $11.3 \%$, averaging $3.3 \%$. Post-operatively it ranged from 13.6 to $34 \%$, averaging $23.46 \%$.

TABLE IV

BROMSULPHALEIN RETENTION VALUES BEFORE AND AFTER PORTACAVAL SHUNT OPERATION

\begin{tabular}{ccc} 
Case No. & Before Operation (\%) & After Operation (\%) \\
\hline 1 & 0 & $27 \cdot 2$ \\
2 & 3 & $16 \cdot 1$ \\
3 & 0.8 & 34 \\
4 & $11 \cdot 3$ & 26.4 \\
5 & 1.4 & 13.6 \\
Average & 3.3 & 23.46
\end{tabular}

\section{DISCUSSION}

Bromsulphalein when injected intravenously is taken up by the parenchymal cells of the liver and is excreted into the bile at a limited speed by an active transport mechanism (Wheeler, Epstein, Robinson, and Snell, 1960). During this process of excretion some of the bromsulphalein is conjugated with amino-acids or peptides. A decrease in the capacity of the liver to remove bromsulphalein from plasma can therefore result from hepatic cell damage when the transport mechanism is deranged. Excretion of bromsulphalein can also be impaired by decreased hepatic blood flow in the absence of hepatocellular 
dysfunction because less bromsulphalein will be presented to the liver, i.e., a prehepatic factor (Lichtman, 1953), and by biliary obstruction even if there is normal blood flow and a normal transfer mechanism, i.e., a post-hepatic factor. The second factor was not found in our cases.

Liver function, as estimated by tests other than the bromsulphalein test, proved to be normal with the exception of a very mild abnormality in the thymol turbidity test in less than half of the cases. Hypoproteinaemia and the rare occurrence of hypoprothrombinaemia were proved not to be due to liver dysfunction since they were corrected by diet and vitamin $\mathrm{K}$ respectively. Furthermore the liver biopsy showed that the lesions were mainly mesenchymal and limited to the portal tracts with minimal damage to the parenchyma; some of the liver cells at the periphery of the lobules may be affected by compression. There was no relation between the results of thymol turbidity tests, liver biopsy, measurement of portal pressure, and the bromsulphalein extraction (Table I). These results provide further evidence that the bromsulphalein test cannot be considered as an accurate measure of hepatocellular function.

Study of the prehepatic factors influencing bromsulphalein retention, namely, the hepatic blood flow and the degree of systemic collateral portal veins, showed that they have a definite relation to the results of bromsulphalein retention. Thus all the patients who retained more than $10 \%$ bromsulphalein showed either diminished hepatic blood flow, significant systemic portal collateral veins, or both. The only exceptions were the three patients who had no significant collateral veins and yet retained more than $10 \%$ of the injected bromsulphalein. It is unfortunate that in none of these three patients was hepatic blood flow estimated, but judging by the size of the liver, which proved in our previous studies (Nomeir, 1960) a useful source of information about hepatic blood flow, we feel that had they had the blood flow estimated, it would have been below $1,000 \mathrm{ml}$. per minute.

The normal liver takes about half an hour to get rid of $90 \%$ of the standard dose of bromsulphalein used in the test. This time is needed to allow for repeated passages of blood through the liver at a rate of about $1,500 \mathrm{ml} . / \mathrm{min}$. In the presence of diminished hepatic blood flow, although 30 minutes are sufficient for the whole blood to recirculate several times through the liver, the total amount that passes during the period of the test is definitely less than the normal. Therefore with diminished hepatic blood flow, liver cells with normal excretory power may not be able to excrete $90 \%$ of the dye. It is thus not surprising that we found that there is more retention of bromsulphalein in the patients with a low hepatic blood flow. Lichtman (1953) is of the same opinion.

Systemic portal collateral veins help to diminish the hepatic blood flow (Nomeir, 1960). Furthermore they prolong the time needed for efficient recirculation even if the hepatic blood flow is not grossly impaired. This explains our findings that retention of the dye was maximum in patients with the most marked portal collateral veins.

The increased retention of bromsulphalein after a portacaval shunt operation is a good example of the influence of the prehepatic factors. Liver function was normal before operation and the retention of bromsulphalein was very low. After the operation, although liver function remained intact, retention of bromsulphalein was markedly increased. The operation creates an augmented systemic portal anastomosis which is associated with a decrease in hepatic blood flow.

We wish to thank Professor M. Salah, under whose direction and supervision this work was carried out, for his help and interest.

\section{REFERENCES}

Bradley, S. E. (1949). Variations in hepatic blood flow in man during health and disease. New Engl. J. Med., 240, 456-461.

- Ingelfinger, F J., Bradley, G. P., and Curry, J. J. (1945). The estimation of hepatic blood flow in man. J. clin. Invest., 24, 890-897.

Kolmer, J. A., Spaulding, E. H., and Robinson, H. W. (1952). Approved Laboratory Technic, 5th ed., p. 252. Lewis, London.

Lichtman, S. S. (1953). Diseases of the Liver, Gallbladder and Bile Ducts, 3rd ed., Vol. 1, p. 271. Kimpton, London.

Nomeir, A. M. (1960). Estimation of hepatic blood flow in bilharzial liver fibrosis. M.D. thesis. Faculty of Medicine, Alexandria University.

Wheeler, H. O., Epstein, R. M., Robinson, R. R., and Snell, E. S. (1960). Hepatic storage and excretion of sulfobromophthalein sodium in the dog. J. clin. Invest., 39, 236-247. 